\title{
Support for Redistribution in Western Europe. Assessing the role of religion
}

\author{
Daniel Stegmueller ${ }^{1}$, Peer Scheepers, Sigrid Roßteutscher, Eelke de Jong
}

Forthcoming in European Sociological Review

\section{Introduction}

Public support for social spending and redistribution are an important constituent of the legitimacy of mature welfare states, who - despite of being in a state of "permanent austerity" (Pierson 2001) - have only implemented rather modest cut-backs (Kuhnle 2000; Huber and Stephens 2001; Swank 2002, 2005). With those sustained levels of provision, someone clearly has to "foot the bill" (Taylor-Gooby 2001).

Who supports those redistributive arrangements and who does not? This question falls squarely in the domain of political sociology which concerns itself with the link between social and political life (Svallfors 2007: 1). An extensive literature has developed explanations based on individual's socio-structural position and institutional feedback effects (see Hasenfeld and Rafferty 1989; Svallfors 1993; Papadakis and Bean 1993; Bean and Papadakis 1998; Evans 1996; Svallfors 1997, 1999, 2002, 2003; Gelissen 2000; Andreß and Heien 2001; Blekesaune and Quadagno 2003; Linos and West 2003; Lipsmeyer and Nordstrom 2003; Mehrtens III 2004; Rudolph and Jillian 2005; Edlund 2006; Meier-Jaeger 2006, 2008, 2009; Blekesaune 2007). However, so far the role of religion as determinant of individual preferences for redistribution has not been the central focus of previous research.

In this paper, we analyze this link between religion and preferences in a comparative perspective in order to answer the following research questions: Do religious individuals differ from their secular counterparts in their support for redistribution? If so, is the effect relevant in size compared to established factors? Is the antagonism between religious and non-religious citizens in modern West European countries (quantitatively) more important than the old Catholic-Protestant divide?

The results of this paper contribute to a growing literature that broadly links religion and attitudes towards the welfare state. Recent examples include van Oorschot (2010) who examines

${ }^{1}$ Nuffield College, University of Oxford, mail@daniel-stegmueller.com 
people's beliefs about moral and economic consequences of welfare policy in the Netherlands and includes religion next to structural location and personal experiences. Religion is also considered in van Oorschot's (2006) study of citizen's perceptions of deservingness of welfare recipients. Similarly, van Oorschot et al. (2005) consider religion in a model of individual's concerns with various recipients of welfare. Generally, the results of those papers indicate that religion is not an important factor for explaining citizen's beliefs about deservingness and the welfare state's moral and economic consequences. Starting from a political economy perspective Scheve and Stasavage (2006) and Chen and Lind (2006) look at religion as a substitute for state-provided insurance and find that religiosity decreases an individual's demand for welfare state spending. Besides those micro-level analyses, scholars using a macro-comparative perspective note the impact of religion on the behavior and strategies of elites during the formative years of Western welfare states (e.g. Castles 1994a, b; Manow and Kersbergen 2008) as well as the distinct impact of Catholic and Protestant traditions on timing and generosity of modern welfare policies (Manow 2002; Kahl 2005; Hicks 2006).

The paper is organized as follows. In the next section we outline the theoretical argument linking religion and redistribution preferences. From this we derive four testable hypotheses in section 3 . We then describe the construction of our country level variables in section 4 . This section also describes the individual level data set, the cumulated European Social Survey from 2002 to 2006. Section 5 presents the multilevel model used and provides details of its estimation. We present estimation results in Section 6 and calculate further quantities of interest to obtain strict hypothesis tests. Finally, Section 7 concludes the paper.

\section{Religion as persistent cleavage}

Contemporary political sociologists usually emphasize the role of social class and other structural factors when trying to explain individual attitudes towards redistribution. For example, in his excellent introduction to the "political sociology of the welfare state", Svallfors (2007) outlines some 'new' cleavages (age and gender) in addition to the traditional workerowner/manager antagonism, but there is no mention of religion as a 'classical' dividing line (Lipset and Rokkan 1967). This is not surprising given the predominant (academic) view that in enlightened and secular societies religion plays a minor role in people's everyday lives. It is seen as a relict of the past, invoked on wedding days and Christmas, but with no further impact on (political) attitudes and beliefs. In political-sociological research, this preconception is reflected by the rather scant attention that has been paid to religious as opposed to class cleavages. Recently, researchers have begun to pay renewed attention to the religious cleavage (e.g. Manza and Brooks 1997; De Graaf et al. 2001; Brooks et al. 2006; Elff 2007).

The process of secularization does not necessarily lead to a decline in the effect of religion on individuals. In a secularizing environment, religion can gain prominence in the political process, when its position on social and moral issues is juxtaposed against secular proposals, that 
are depicted as leading to the decline of a society's moral order (Madeley 1991). ${ }^{2}$ As Inglehart observes, individuals who oppose the majority's values, are "galvanized into unusually active and disruptive forms of behavior, in order to defend their threatened values" (Inglehart 1997: 281). Especially in Western countries, characterized by far progressed secularization, individuals "who retain their religious identity may oppose other aspects of secularization processes, showing increasing political differences in comparison to non-religious voters" (Brooks et al. 2006: 93, our emphasis). These lines of conflict start to become visible to such an extent that some researchers speak of a "good gap" in political behavior (Olson and Green 2006). Therefore, rather than leading to a decline in the importance of religion per se, secularization shifts the basis of the religious cleavage from the antagonism between Catholic and Protestant denominations to the distinction between secular and religious individuals (Wuthnow 1988). These shifts gradually make religion, rather than class, the most important cleavage in modern societies. As Martin Elff concludes in his study of cleavages and voting in European democracies:

"Reports of the death of social cleavages are exaggerated. While the consequences of class positions seem to have weakened in some of the countries, the consequences of the division between religious and secular people have not" (Elff 2007: 289).

In the light of these findings, we employ the notion of religious cleavage beyond research on voting behavior. Using a broader definition of cleavage as "borders between social categories" which generate the potential of social conflict (Svallfors 2007: 9), we investigate effects of individual's cleavage position on redistribution attitudes. The mechanism linking cleavage position and preferences is a process of identification: Individuals who identify with a religious group in a society will adjust their norms and preferences to be similar to the ones dominant in that group (for an extensive treatment see Shayo 2009). This, of course, raises the question of what religion's position towards state redistribution is and how it came about.

On first thought, one might expect religious individuals to be supportive of redistribution. After all, religious individuals are known to donate time and money to help the less fortunate (for an overview see Wiepking and Bekkers 2009). However, the religious cleavage perspective stresses the long history of the church-state conflict over the provision of welfare. This antagonism is the result of critical junctures in the history of church and state. The Catholic church has always been opposed to the state's intervention in social policy matters. According to the principle of subsidiarity, it preferred local solutions provided by church organizations (Kahl 2005: 98-101). In contrast, the Protestant church and the state had a symbiotic relationship during the reformation period. The Protestant church was able to use those ties to the state to enforce its views of strict social policies necessary to maintain social order (Kahl 2005, Rossteutscher 2009: $127 \mathrm{ff}$.). But this relationship was destroyed during the construction of the modern nation state, where conflicts over moral authority and material resources were decided in favor of the state (Lipset and Rokkan 1967: 50). From welfare provision to

\footnotetext{
${ }^{2}$ Whereas classical sociological writers often portray religion as "social glue" of a society, historically, it has at least to the same extent functioned as source of disagreement and conflict
} 
the education of children, the state wrested major domains of public life from the churches. They became one organization among many in the realm of civil society and as a result were less able to form social policy. This produced a continuously increasing gap between religious conceptions of welfare and social order and the rules and principles implemented by the secular state and lead to a "pronounced anti welfare-state position" of (especially Protestant) churches and parties (Manow 2002:206, our translation).

Hence we argue that contemporary religious individuals oppose redistributive welfare polices. Whilst not necessarily opposed to the general idea of ameliorating the inequalities and social ills generated by markets, they object to the provision of welfare by the secular state. Welfare state policies are based on the notion of rights (Marshall 1950), ignoring religious or moral criteria for the provision of welfare. In contrast, providing welfare voluntarily, through donations or participation in charitable church activities, leaves the form of help and the decision of who is considered as deserving or not at the (religious) individual's discretion (cf. de Swaan 1988; Schneider and Ingram 1993; van Oorschot 2000; Deacon 2002).

\section{Religion and redistribution from an economics of religion perspective}

While the cleavage approach stresses identification or religious belonging, economics of religion scholars (Chen and Lind 2006; Scheve and Stasavage 2006) focus on religious behavior. As a result, they provide a different mechanism to connect individual religiosity and preferences for redistribution. Following the standard economics of religion approach (e.g. Stark and Iannaccone 1994), demand for religion is taken as given and what is modeled is how an individual divides his time between non-church and church activities. Integration into a religious community helps to insulate individuals against adverse life events (e.g. becoming sick or unemployed) by providing them with help both in the material (money, unpaid help), as well as a 'psychic' (coping with a difficult life situation) sense (Pergament 1997, 2002; Clark and Lelkes 2005). From this perspective it is straightforward to conceptualize religiosity and state welfare spending as substitute goods: regular churchgoers who "privately insure themselves via religion" (Scheve and Stasavage 2006: 263) demand less welfare provision by the state.

\section{Hypotheses}

After this more general account of the role of religion in contemporary Western societies, we derive four testable hypotheses.

Given the persistent importance of religion as a societal cleavage and its formation through an extensive period of church-state conflict about welfare provision and social order, religious individuals prefer to ameliorate social ills through their churches and organizations and not through secular state programs. From this line of reasoning follows the central hypothesis of this study: Individuals that identify with (any) one of the major Christian religions will be opposed to income redistribution by the state (H1). 
Previous research on religion and the welfare state stresses differences between denominations because of the strong link between Catholicism and Christian Democratic parties (e.g. Esping-Andersen 1990; Kersbergen 1995; Manow 2002; Manow and Kersbergen 2008). This suggests that Catholics may be less opposed to state redistribution than Protestants (Kahl 2005; van Oorschot 2010: 22). However, the process of secularization renders these differences less salient, so that the Protestant-Catholic dichotomy is gradually replaced by the secular-religious cleavage (Wuthnow 1988; Inglehart 1997; Olson and Green 2006). Therefore, we expect that differences between religious and secular individuals are larger than differences between Catholics and Protestants (H2), thus demonstrating the importance of the religious-secular divide.

While the previous hypotheses were concerned with an individual's religious self-identification, or religious belonging, the economics of religion perspective stresses the importance of religious practice. According to this view, spending more time participating in organized religious activities decreases one's demand for social protection by the state (Scheve and Stasavage 2006: 267). If this proposed relationship holds, individuals who attend church frequently will show less support for redistribution (H3).

Religion also exerts an influence on the contextual level. Where religious groups constitute a strong opponent to the secular part of society, they are more likely to make their opinions heard. Therefore, each individual is more likely to encounter negative views on the redistributive role of the state. As a results, we expect that the higher the level of religious polarization in a country is, the lower its citizen's support for redistribution will be (H4).

\section{Established explanations}

Besides these new hypotheses concerning the role of religion, a number of established explanatory factors, both on the individual and country level, have to be considered (for an overview see Meier-Jaeger 2006). Higher income, as well as education leads to opposition to redistribution (Meltzer and Richards 1981; Moene and Wallerstein 2001). ${ }^{3}$ Contrary, individuals who face heightened risk of income loss (e.g. the short term employed and families with children) are expected to be supportive of redistribution. It has been shown that individuals doing housework full-time, are unemployed, disabled or pensioners - the so called transfer classes (Alber 1984) - support redistribution as well. Individuals in advantaged class positions, especially members of the service classes who usually enjoy long-term contracts and low chances of dismissal will not support redistributive arrangements (Goldthorpe 1995; Goldthorpe and McKnight 2006). Similarly, individuals who are self-employed are expected to oppose welfare state intervention in market generated income distributions. Contrary, workers, especially those in routine manual occupations, are expected to have strong preferences for redistribution (Svallfors 2004). Finally, institutional differences between welfare-states have been show to influence citizens preferences (Arts and Gelissen 2001). We expect that

${ }^{3}$ For a more sophisticated position on skills see Iversen and Soskice (2001). 
especially liberal welfare policy patterns will diminish individual support for redistribution (Hicks and Kenworthy 2003).

\section{Data and Measurement}

\section{Individual level data}

To analyze the questions posed above, we use the European Social Survey (ESS) 2002-2006 cumulated file which provides data on 79,679 individuals from sixteen West European countries: Austria, Belgium, Denmark, Finland, France, Germany, Ireland, Italy, Luxembourg, the Netherlands, Norway, Portugal, Spain, Sweden, Switzerland, and the United Kingdom. Since countries did not necessarily participate every year, 41 country-years are used in the analyses. The ESS ensures exceptionally high standards regarding the comparability of questionnaires, sampling designs and population coverage, making it an ideal tool to analyze a large number of countries simultaneously. Details on sampling designs, questionnaire translation, fieldwork and data documentation are available at www.europeansocialsurvey.org.

The ESS probes a respondent's support for redistribution using a straightforward question: "please say to what extent you agree or disagree with the following statement: The government should take measures to reduce differences in income levels". Responses are recorded using a five-point agree-disagree scale. They do not follow a normal distribution, but are left skewed with the majority of European citizens showing some support for redistribution. However, as can be seen in Table 1 on the following page, support is not unconditional, as the differences between the "strongly agree" categories show: variation in the level of strong support for redistribution ranges from only 10 percent in Denmark - hinting a possible ceiling effect - to over 43 percent in France.

Table 2 shows descriptive statistics for the individual level variables included in the analyses. Religious denomination is a nominal variable assigning individuals to one of the following categories: No denomination, Catholics, Protestants or other. ${ }^{4}$ The cross-national scope of the European Social Survey imposes some restrictions here, and finer distinctions between local religious sects can not be detected in this study. Church attendance is captured using a quasimetric variable for the frequency with which our respondents visit church (if at all), ranging from never to daily attendance.

A respondent's education is assessed using the years of schooling she has accumulated. Income is measured on the household level using a twelve-category scale in 500 Euro increments. ${ }^{5}$ Membership in one of the transfer classes is included as a dummy variable for being unemployed, retired, or not in labor force for a variety of reasons (permanent disability, doing housework etc.). Two further dichotomous indictors capture what we have labeled economic risks: being on a temporary, short-term contract and having one or more children living in

\footnotetext{
${ }^{4}$ This is a rather heterogeneous group of muslims and Eastern faiths which are too small to include on their own.

${ }^{5}$ Respondents had the possibility to give weekly, monthly or yearly income figures.
} 
Table 1: Support for income redistribution in Western Europe. Means, standard deviations and percentage of respondents placing themselves in the highest category ("strongly agree")

\begin{tabular}{lrrr}
\hline & & & strongly \\
& mean & sd & agree \\
\hline Portugal & 4.21 & 0.78 & 38.7 \\
France & 4.09 & 1.07 & 43.8 \\
Italy & 4.06 & 0.89 & 33.9 \\
Spain & 4.04 & 0.87 & 30.7 \\
Finland & 3.97 & 1.01 & 34.4 \\
Austria & 3.79 & 1.07 & 28.0 \\
Ireland & 3.76 & 0.93 & 18.3 \\
Belgium & 3.72 & 1.08 & 24.4 \\
Sweden & 3.70 & 0.93 & 17.0 \\
Norway & 3.65 & 1.00 & 18.2 \\
Switzerland & 3.60 & 1.06 & 17.4 \\
Luxembourg & 3.60 & 1.16 & 22.7 \\
Germany & 3.52 & 1.08 & 16.9 \\
Great Britain & 3.50 & 1.03 & 14.0 \\
Netherlands & 3.44 & 1.08 & 13.9 \\
Denmark & 3.02 & 1.15 & 9.5 \\
\hline
\end{tabular}

Note: Based on multiply imputed data from ESS 2002-2006. Variable is measured on a five point ordinal scale. 
Table 2: Descriptive statistics of individual level variables (means and standard deviations).

\begin{tabular}{lrr}
\hline & mean & sd. \\
Income & 6.91 & 2.32 \\
Education & 12.03 & 4.21 \\
Age & 47.31 & 18.09 \\
Female & 0.53 & 0.50 \\
Church attendance & 2.48 & 1.51 \\
Denomination & & \\
No Religion & 0.40 & 0.49 \\
Catholic & 0.36 & 0.48 \\
Protestant & 0.21 & 0.41 \\
Other & 0.03 & 0.17 \\
Transfer classes & & \\
Unemployed & 0.04 & 0.20 \\
Retired & 0.24 & 0.42 \\
$\quad$ Not in Labor Force & 0.20 & 0.40 \\
Economic risk & & \\
Temporary contract & 0.18 & 0.39 \\
Children in household & 0.37 & 0.48 \\
Social Class & & \\
Higher Salariat & 0.09 & 0.29 \\
Lower Salariat & 0.18 & 0.39 \\
Intermediate occupations & 0.09 & 0.29 \\
Self-employed / small employers & 0.08 & 0.28 \\
Lower supervisory / technicians & 0.11 & 0.31 \\
Lower sales / service / clerical & 0.10 & 0.30 \\
Lower technical & 0.08 & 0.27 \\
Routine & 0.15 & 0.35 \\
\hline
\end{tabular}

Note: Multiply imputed data from ESS 2002-2006

the household. Social class is included by coding detailed occupation-by-employment-status units into a categorical class scheme. More precisely, we use the European Socio-economic Classification which provides a harmonized and validated adaptation of the widely used EGP (Erikson et al. 1979) class scheme (see Rose and Harrison 2010).

\section{Dealing with missing information: multiple imputation}

Missing data is an ubiquitous feature of surveys (Groves et al. 2001). Even when extra precautions are taken to ensure maximal response rates (for a discussion about the ESS see Stoop 2005: ch. 10), item non-response remains a concern. While the percentage of missing item responses is generally reasonably low for the variables used in this study (between one and two percent), 22.3 percent of all respondents refused to provide information about their income. It is not possible to ignore this missing data, given that income is related strongly to redistribution preferences according to classic political economy theories (Meltzer and Richards 1981). The default approach for dealing with missing cases is listwise deletion - i.e. excluding all 
individuals with missing data on one of the model variables. However, this strategy leads to seriously biased estimates when the mechanism that produces missingness is not completely random (Allison 2001; King et al. 2001; Little and Rubin 2002: ch. 1). This problem has been ignored by previous studies. ${ }^{6}$

An appropriate solution is to use a multiple imputation approach (Rubin 1996). Values for the missing cells are generated according to a probabilistic mechanism and several $(m \geq 2)$ imputed data sets are created. The final quantities of interest are obtained by combining estimates from each of the $m$ individual datasets (Rubin 1987). This reflects the uncertainty introduced by the imputation procedure and leads to adequate (conservative) estimates of standard errors. ${ }^{7}$ We use multiple imputations based on chained regression equations (Raghunathan et al. 2001; Buuren et al. 2006; Buuren 2007), where imputations are carried out sequentially for each single variable. Missing values are replaced with predictions from regression models appropriate for the measurement level of each variable. Iteratively repeating this process realizes a Gibbs sampling scheme, which, when convergence of parameter values is achieved, gives results analogous to draws from a multivariate distribution (Abayomi et al. 2008: 279). We apply this approach to the pooled ESS data (stratified by country) using further available individual characteristics in the imputation model, which leads to an increase in the precision of the imputations. ${ }^{8}$ After ensuring that the chains have converged to their steady state using the Gelman-Rubin diagnostic ${ }^{9}$ and checking that sensible values were imputed using graphical displays as suggested by Abayomi et al. (2008), we generate three imputed data sets which constitute the basis of subsequent analyses and descriptive statistics presented in this paper.

\section{Religious polarization}

To model the importance of religion as a societal dividing line, we need a measure that accounts not only for the size of religious and secular groups, but also for the distance between them. In a classic paper, Esteban and Ray (1994) provide a sophisticated account of how to construct a measure of polarization using group size and group distance. Finding a distance measure is not easy, which is why it is often left out of widely used polarization and fractionalization indices (e.g Montalvo and Reynal-Querol 2002, 2005a, b; Alesina et al. 2003).

\footnotetext{
${ }^{6} \mathrm{~A}$ notable exception is the replication study by Linos and West (2003).

${ }^{7} \mathrm{~A}$ widely used approach to get imputation values is to consider the data as coming from a multivariate normal distribution from which values are drawn. Imputations for variables which are clearly not normal - gender being the prime example - are rounded to sensible values afterwards (see for example King et al's (2001) Amelia routine). Since the majority of this study's variables are categorical - including the dependent one this procedure is questionable and is not used here.

${ }^{8}$ This constitutes an additional advantage of multiple imputation over ad-hoc methods, since we can obtain imputations based on more information than used in the analysis model - yielding so called "superefficient" imputations (Rubin 1996). Variables used are: discretion to organize tasks at work, prior unemployment, living in a rural area and household size.

${ }^{9}$ Since multiple imputation using chained equations generates several (in our case three) sampled chains, one can use Gelman and Rubin's diagnostic based on multiple sequences here (Gelman and Rubin 1992).
} 
However, using distances is essential to the definition of polarization: holding the size of opposing groups constant, an increase in distance between those groups is hypothesized to to lead to higher conflict potential (Duclos et al. 2004; Permanyer 2008). Using an ESS question which asks all individuals about their subjective assessment of their strength of religiosity, I create average distances between those belonging to a denomination and those who do not (for a similar approach using World Value Survey data, see Permanyer 2008). ${ }^{10}$ Building on Esteban and Ray (1994) I model polarization, $P$, between religious and secular groups as a function of group size and distance:

$$
P(\pi, y)=\pi_{r} \pi_{s} \operatorname{abs}\left(y_{r}-y_{s}\right)
$$

Group size is captured in the first half of the equation, where $\pi_{r}$ and $\pi_{s}$ denote the population share of the religious and secular group, respectively. The second half of the equation adds distance, or alienation (Esteban and Ray 1994: 831), between groups by including the absolute distance in religiosity, $y$, between the religious and secular. ${ }^{11}$

Table 3 on the next page shows for each country the size of the religious group and its distance in religiosity to the secular group. It reveals clear country differences: religious-secular distance is high in Germany, Belgium and Spain, whereas it is rather low in the Scandinavian countries. The resulting measure of religious polarization is given in the last column. We see rather large values in countries like Germany, France, or Belgium, where the religious group constitutes about half of the population and where the religious distance between both groups is large. The correlation of our polarization measure with the widely used fractionalization index of Alesina et al. (2003), which ignores the distance between religious and secular individuals, is $0.57 .{ }^{12}$

\section{Welfare state characteristics}

A study on redistribution preferences would not be complete without taking welfare state policies and structures into account. A straightforward approach is to include dummy variables representing three (or more) of Esping Andersen's (1990) famous regime types (previous large-N studies using this approach include Gelissen 2000; Arts and Gelissen 2001; Lipsmeyer and Nordstrom 2003; Svallfors 2003). ${ }^{13}$ However, treating regimes as monolithic blocks might obscure important differences between countries. After all, Esping-Andersen's

\footnotetext{
${ }^{10}$ The exact question wording is "Regardless of whether you belong to a particular religion, how religious would you say you are?". Responses are recorded on a 10 point scale ranging from "not at all religious" to "very religious".

${ }^{11}$ Most of the theoretical derivations of the polarization measure are done with respect to income polarization. However, there is nothing in the assumptions of these measures that would preclude their application to other forms of "social polarization" (Duclos et al. 2004).

${ }^{12}$ However, one should note that even when using this simpler fractionalization measure, our substantive results do not change.

${ }^{13}$ Studies concentrating on a small number of countries usually select countries taken as 'typical' manifestations of welfare regimes, e.g. Svallfors 1993, 1999, 2002; Bean and Papadakis 1998; Linos and West 2003
} 
Table 3: Size of religious group, religious distance and polarization in Western European countries.

\begin{tabular}{lccc}
\hline & $\begin{array}{c}\text { Size of } \\
\text { Religious Group }\end{array}$ & $\begin{array}{c}\text { Mean } \\
\text { Religious Distance }\end{array}$ & $\begin{array}{c}\text { Religious } \\
\text { Polarization }\end{array}$ \\
\hline Austria & 0.68 & 3.01 & 0.65 \\
Belgium & 0.44 & 3.40 & 0.84 \\
Denmark & 0.60 & 2.28 & 0.55 \\
Finland & 0.69 & 1.61 & 0.34 \\
France & 0.46 & 3.46 & 0.86 \\
Germany & 0.53 & 3.84 & 0.95 \\
Great Britain & 0.47 & 3.19 & 0.79 \\
Ireland & 0.83 & 2.55 & 0.37 \\
Italy & 0.79 & 3.26 & 0.54 \\
Luxembourg & 0.71 & 2.61 & 0.54 \\
Netherlands & 0.42 & 3.29 & 0.80 \\
Norway & 0.50 & 2.02 & 0.51 \\
Portugal & 0.85 & 3.64 & 0.46 \\
Spain & 0.73 & 3.56 & 0.71 \\
Sweden & 0.30 & 2.53 & 0.53 \\
Switzerland & 0.66 & 2.14 & 0.48 \\
\hline
\end{tabular}

Note: Size of religious group and religious distance calculated from multiply imputed data from ESS 2002-2006

regimes are a theoretical ideal-type and existing countries do not map easily onto them, as demonstrated by a recent research project by Lyle Scruggs (see Scruggs 2006; Scruggs and Allan 2006, 2008).

A more promising route is to use a range of empirical indicators of welfare state characteristics (e.g. Blekesaune and Quadagno 2003; Blekesaune 2007; Meier-Jaeger 2009) to map countries in a low-dimensional 'welfare-state space'. We use eight indicators to capture differences in economic and social policies (descriptive statistics are given in Table 4 on the following page). An indicator of overall welfare effort is the level of social expenditure: the proportion of a country's GDP that is spent on social services, cash and in-kind benefits (OECD 2008b). Disadvantages of this widely used measure include its (a) very general nature and (b) dependence on the level of economic performance of a country. To capture more nuanced differences in welfare state generosity, we use unemployment benefits (OECD 2004a) and pension payments (OECD 2005) calculated as replacement rates of the income of an average production worker. A defining feature of conservative social policy is its concentration on work-related policies, protecting the labor market status of the (male) breadwinner, who supports his family. The OECD's index of employment protection legislation provides a measure of the extent to which legislation is passed that is favorable to labor market insiders, protecting them from individual or collective dismissal or short-term employment contracts (OECD 2004b, data for Luxembourg are from OECD 2006: ch. 3). A country's level of inequality is measured using the Gini coefficient (available for the mid nineties) calculated from detailed 
Table 4: Descriptive statistics of macro level variables (means and standard deviations).

\begin{tabular}{lrr}
\hline & mean & sd \\
\hline Welfare state characteristics & & \\
Social expenditure (in \% GDP) & 23.86 & 3.61 \\
Unemployment benefits (repl. rate) & 0.61 & 0.19 \\
Pensions payments (repl. rate) & 0.73 & 0.18 \\
Employment protection legislation & 2.34 & 0.66 \\
Parental leave (in FTE weeks) & 16.86 & 17.40 \\
Accumulated left seats (since 1960) & 16.41 & 7.80 \\
Economic Integration & 3.56 & 0.97 \\
Inequality (GINI index) & 0.29 & 0.04 \\
\hline
\end{tabular}

Note: For sources, see text.

micro-data obtained in the Luxembourg Income Study and compiled by the OECD (2009). The percentage of seats accumulated by left parties since 1960 is calculated from Armingeon et al. (2008) and captures their distinct influence on welfare state policies, especially in Scandinavian countries. Siaroff's scoring of the level of economic integration captures the extent to which tripartite negotiations between employer and employee organizations and the state are used to solve industrial conflicts and to coordinate macroeconomic policy (Siaroff 1999). Finally, as a proxy for the extent to which welfare states differ in their family policies (see Orloff 1993; Esping-Andersen 1999), we use the length of the parental leave period following the birth of a child calculated as full-time-wage equivalent weeks to harmonize the rather different replacement rates between countries (OECD 2008a).

In line with previous welfare-state research, those variables are highly correlated, hinting that they are generated by a small number of underlying factors. Research by Hicks and Kenworthy (2003) has shown that Esping-Andersen's (1990) three dimensions of social policy - social-democratic, liberal, conservative - can be reduced to a two dimensional welfare space, since liberal and social-democratic policies are "opposing poles of a single dimension" (Hicks and Kenworthy 2003: 32). Following their argument, we estimate a two-dimensional Bayesian confirmatory factor model (Congdon 2006: ch. 12; Lee 2007), which is displayed in Table $5 .{ }^{14}$ This indeed reveals a rather clear structure of loadings, similar in substance to the one found by Hicks and Kenworthy, with dimension one contrasting social-democratic versus liberal policies and dimension two capturing the extent to which welfare states posses

\footnotetext{
${ }^{14}$ More precisely, we estimate the following specification: $\boldsymbol{x}_{i}=\boldsymbol{\Lambda} \boldsymbol{\phi}_{i}+\epsilon_{i}, \quad \epsilon_{i} \sim N(0, \boldsymbol{\Psi})$, where $\boldsymbol{x}_{i}$ is a vector of individual responses, $\Lambda$ is a $8 \times 2$ matrix of factor loadings, $\phi_{i}$ contains countries' scores on the latent variables and $\epsilon_{i}$ is an error term which is normally distributed over countries. The model is identified by fixing one item for each factor; social expenditure on factor one and employment protection legislation on factor two. Using independent normal priors for scores and loadings and inverse gamma priors for elements of $\Psi$ completes the Bayesian specification of this model. We estimate the model using Markov Chain Monte Carlo (via Gibbs sampling) which provides a straightforward assessment of the importance (or 'significance') of the factor loadings by inspecting their empirical $2.5 \%$ and $97.5 \%$ quantiles.
} 
Table 5: Results from two-dimensional factor analysis of welfare state characteristics. Loadings and uniqueness.

\begin{tabular}{lrrr}
\hline & Dim. 1 & Dim. 2 & Unique. \\
\hline Social expenditure & 1.00 & $n s$ & 0.50 \\
Unemployment benefits & 0.86 & $n s$ & 0.37 \\
Economic integration & 0.88 & $n s$ & 0.45 \\
Accumulated left seats & 0.85 & $n s$ & 0.47 \\
Parental leave & 0.96 & $n s$ & 0.36 \\
Inequality (Gini index) & -0.97 & $n s$ & 0.28 \\
Employment protection legislation & $n s$ & 1.00 & 0.04 \\
Pensions payments & $n s$ & 0.74 & 0.48 \\
\hline
\end{tabular}

Note: Non-significant loadings are denoted by $n s$. Based on 40.000 MCMC draws obtained via Gibbs sampling. Correlation between both dimensions is 0.02 .

features of conservative social policy. ${ }^{15}$

The distribution of countries in this two dimensional space is displayed in Figure 1 on the next page which shows scores for each country. We see the usual arrangement of countries along the predominant liberal-social-democratic dimension and a separate group of highly conservative countries. Furthermore, the distribution of countries emphasizes that putting them into mutually exclusive regime groups obscures some important policy differences. For example, while Great Britain and Ireland, two countries of the 'liberal group', are indeed close to each other; Sweden and Norway, generally classified as genuinely social-democratic, occupy quite distinct positions regarding the extent to which liberal policy elements are present.

\section{Analytical strategy}

This combined macro-micro data set is analyzed using the following parametric specification, where $c$ denotes the response category chosen by individual $i$ in country-year $j, x_{i j p}$ denotes $p$ individual level covariates and associated effect parameters $\beta_{p}$, where some of them may vary across country-years (yielding so called 'random slopes') with associated effect parameters $\beta_{r j}$. Finally $u_{j q}$ represents $q$ country level variables and their effect parameters $\gamma_{q}$ :

\footnotetext{
${ }^{15} \mathrm{~A}$ one-dimensional factor model strongly suggests that pensions and employment protection legislation belong on a separate dimension. A model with three factors yields only insignificant loadings on the third factor.
} 


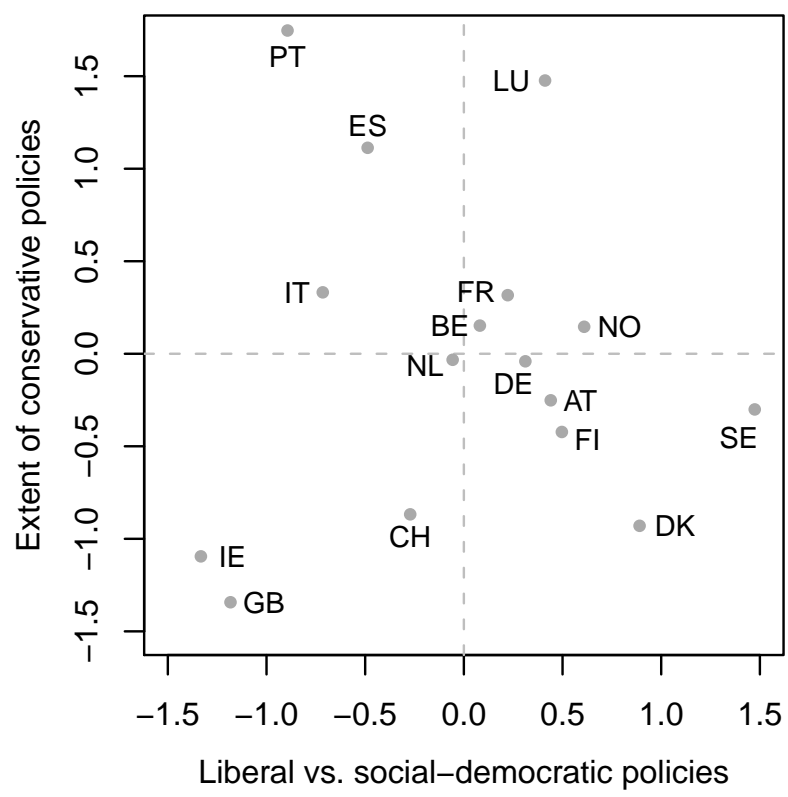

Figure 1: Country positions in two dimensional welfare-policy space (scores from two-dimensional factor model)

$$
\begin{aligned}
& \operatorname{logit}\left[\operatorname{Pr}\left(y_{i} \leq c\right)\right]=\tau_{c j}+\sum_{p=1}^{P} \beta_{p} x_{i j p}+\sum_{r=1}^{R} \beta_{r j} x_{i j r} \\
& \tau_{c j} \sim N\left(\gamma_{0}+\sum_{q=1}^{Q} \gamma_{q} u_{j q}, \sigma_{\tau}^{2}\right) \\
& \beta_{r j} \sim \operatorname{MVN}\left(0, \sigma_{\beta_{r}}^{2}\right)
\end{aligned}
$$

The cut-points $\tau$ are constrained to be monotonically decreasing and identical for all covariates, leading to the well-known ordered logit model with proportional odds (McCullagh 1980; Agresti 2002). To capture unobserved differences in response behavior of individuals from different countries, the cut-points are free to vary across countries (cf. Molenberghs and Verbeke 2005: ch. 18) by giving them a normal distribution, with the mean influenced by country level variables and freely estimated variance $\sigma_{\tau}^{2}$ (see Sun et al. 2000; Congdon 2005; Gill 2008).

We estimate the model in a Bayesian framework (see Lynch 2007 for introduction), using noninformative independent normal priors for the regression coefficients $p$ and $q$ with mean zero and variance 1000. For the multivariate group-level parameters (see model 3 of Table 6) intercept $\alpha$ and $R$ random slopes - we use an inverse Wishart prior with 4 degrees of freedom 
and scale matrix $I * 0.005$ (c.f. Gelman et al. 2004). ${ }^{16}$ Models are estimated using a MetropolisHastings sampler run for 220,000 iterations, with the first 20,000 iterations discarded as burnin. Chains were thinned by a factor of ten to yield 20,000 samples on which the following inferences are based. ${ }^{17}$

Table 6 shows posterior means and standard deviations from three estimated models of increasing complexity. After controlling for micro-level composition effects the intra-class correlation of Model 1 is estimates as 0.071 with a 95\% confidence bound ranging from 0.053 to 0.092. ${ }^{18}$ This indicates that significant country differences exist: seven percent of the overall variance is due to country characteristics. Including our three central macro-level predictors reduces this measure to 0.046 , while providing a better fit as indicated by the BIC difference (Raftery 1995). Model 3 realizes a more complex specification where denomination effects are allowed to vary over countries ('random slopes'). The historical developments of church-state conflict, as well as modernization processes more generally, vary between Western European countries, and this model allows for unobserved effects of historical and cultural peculiarities - providing a stricter test of our hypotheses.

\section{Results and Discussion}

Looking first at the estimated effects of religion in model 1, Table 6 on the following page, we see our first hypothesis confirmed: Catholics and Protestants both strongly oppose redistribution at a level comparable to that of five more years of education or an increase in net household income of 500 Euro. The effect of church attendance is an order of magnitude smaller, but highly statistically relevant, confirming hypothesis 3 . However, to obtain the same effect strength as denomination, an individual would have to increase his or her frequency of church attendance from showing up only on holidays to attending services several times a week. The estimated effects of religion remain stable when we include country characteristics in model 2. In our final model we allow the effect of religious denomination to vary over countries, in order to capture unobserved country differences in the role of religion. Here, differences between both denominations are discernible. While the effect for Protestants remains virtually the same, the estimate for Catholics becomes smaller. This is a result of the larger variance of the Catholic effect over countries. It is more than three times larger than the variance for the Protestant slope (see Country level variances in model 3). However, the variances of both denomination slopes are rather small compared to the differences between countries, captured by the variance of the intercept.

In light of these results, what can we say about hypothesis 2? Using the results from model 3 , we calculate the difference between the effects of being a Catholic or a Protestant (and its

\footnotetext{
${ }^{16}$ If only a random intercept is modeled (models 1 and 2 of Table 6), I use a uniform prior between 0 and 100 on its standard deviation.

${ }^{17}$ Several tests are used to diagnose the absence of convergence (c.f. Brooks and Roberts 1998). Furthermore, using priors with even larger variances did not change results.

${ }^{18}$ Intra-class correlation is calculated as $0.251 /\left(0.251+\pi^{2} / 3\right)$. In the Bayesian framework, we can get a $95 \%$ confidence bound for the ICC from the MCMC output.
} 
Table 6: Results from hierarchical ordered logit models. Estimates (posterior means) and standard errors (posterior standard deviations).

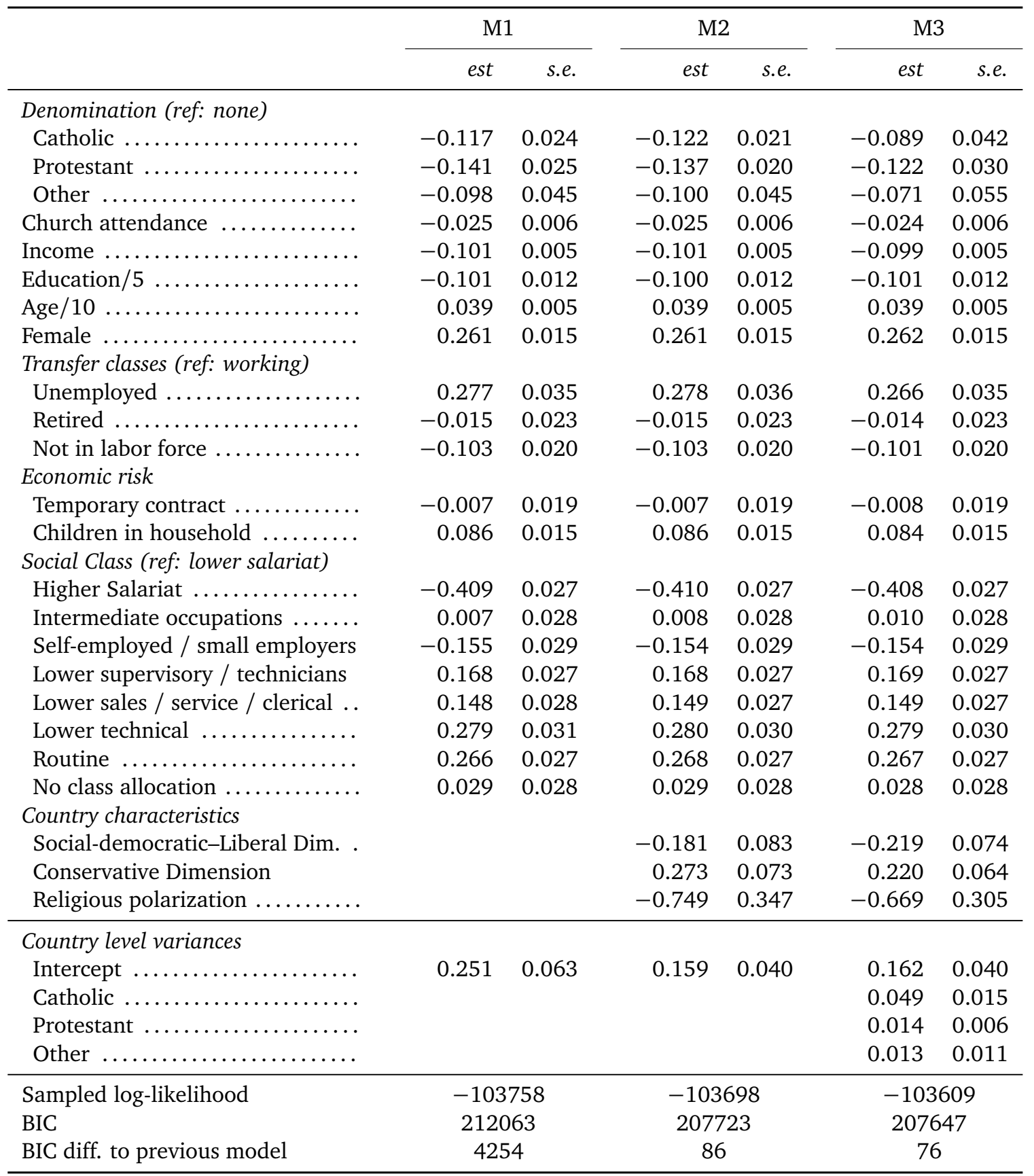

Note: Estimated category intercepts are omitted to save space. BIC difference for M1 refers to comparison to a variance component model with no predictors. Multiply imputed data from ESS 2002-2006. Effective sample size is 79,679. Imputations combined according to Rubin 1987. Based on 20.000 MCMC draws. 


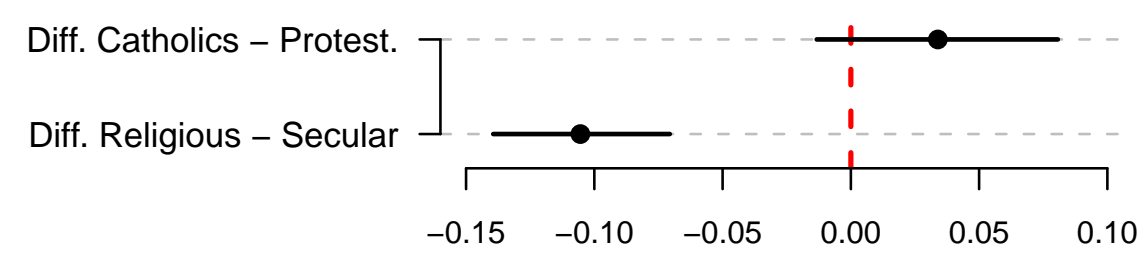

Figure 2: Effect difference between Catholics and Protestants and effect difference between Religious and Secular Individuals. Differences and associated 95\% confidence bounds

associated standard error), as well as the difference between religious individuals and secular individuals. If hypothesis 2 is correct, we expect to see larger differences between the latter. ${ }^{19}$ Figure 2 shows that the difference (or cleavage) between religious and secular individuals is much larger than the old division between Catholics and Protestants. The latter is so small that is is statistically indistinguishable from zero. While simple eyeballing makes this result apparent, a more formal test is to examine the difference between those two differences (since the difference between a significant and non-significant effect is not necessarily itself significant, as elaborated by Gelman and Stern 2006). The Bayesian approach allows for an easy calculation of this difference and its uncertainty from the generated MCMC samples. This yields a difference of 0.139 with a standard error of 0.025 , thus lending clear support to our second hypothesis.

Our findings for the contextual effect of religion confirm hypothesis 4. The degree of religious polarization exerts a negative effect on citizen's preferences for redistribution, even after taking welfare-state differences into account. To better visualize the effect of these country characteristics, we calculate the predicted probabilities of fully supporting redistribution (i.e. responding in the highest possible category) for an average individual. Varying the effect of religious polarization while holding all other factors constant, Figure 3 shows that polarization reduces the level of support from around nineteen to thirteen percent. Regarding welfare state policies, more liberal welfare policies go hand in hand with lower levels of support for redistribution, while conservative policies have the opposite effect. Both are comparable in size to that of religious polarization, as shown in the last two panels of Figure 3 on the following page. This clear-cut finding stands in contrast to the more mixed results of previous research (see Svallfors 2003) and strengthens the argument that operationalizing welfare policies as continuous dimensions instead of regime dummies has clear analytical advantages. Moreover, the finding that conservative welfare policy patterns increase citizen's support for redistribution, is in line with recent results by Meier-Jaeger (2009).

Estimates for established explanatory individual level factors largely show the expected directions and are stable across model specifications. Individuals with higher levels of education, those who receive larger incomes, are self-employed or employed in a service class profession clearly oppose redistribution. On the other hand, those working in technical and routine

\footnotetext{
${ }^{19}$ 'Religious individuals' means Catholics and Protestants combined. However, including the "other" category as well does not change substantive results.
} 


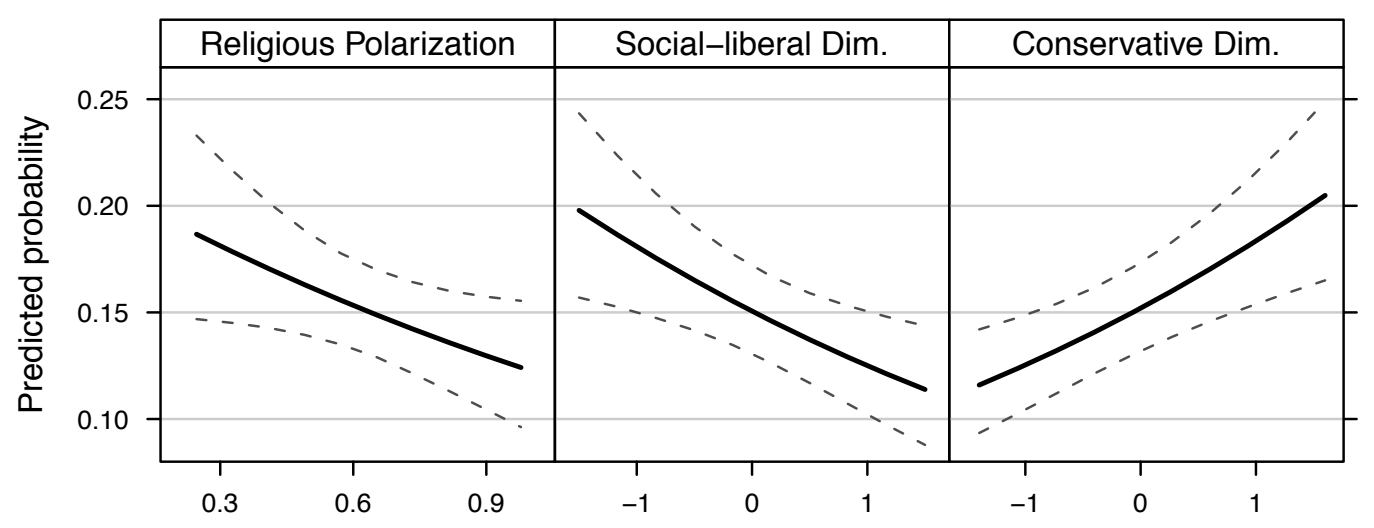

Figure 3: Effects of country characteristics on probability of full support for redistribution holding other factors constant. Predicted probabilities and 95\% confidence bounds for an average individual.

manual occupations, as well as the currently unemployed are in support of it. Individuals who are not part of the labor force (mainly students and people doing housework) show a clear aversion against income redistribution, which was not expected given the "transfer classes" argument. Finally, support for redistribution is also high among older individuals, those who have children living in the household and women. The large gender effect is rather remarkable given that we have already taken income and labor market position into account.

\section{Conclusion}

In this study we examined the effect of religion, both as denomination and participation, on individual preferences for income redistribution through the state. Starting from a cleavage based perspective that stresses the role of social identities for the formation of beliefs, attitudes and preferences, we hypothesized that the historical church-state conflict over mode and means of welfare provision will manifest itself in individual preferences. Individuals who place themselves on the religious side of the religious-secular divide were expected to oppose redistribution through governmental action. Employing Bayesian hierarchical ordered logit models, we confirmed that Protestants and Catholics do indeed show substantial opposition to income redistribution. The strength of this effect is comparable to a seizable increase in income or education. This strong effect of denominational identification shows that motivations beyond self-interest determine the extent to which citizens support or oppose redistributive policies. Contrarily, the comparatively less relevant effect of church attendance underscores the fact that an individual's cleavage position and the associated set of ideas and values is the most important driving force shaping preferences - and not the integration in religious groups and the (in-) tangible benefits it might bring (as argued by economics of religion scholars).

Moreover, we argued that in modernized secular societies the main dividing line regarding religion is no longer between Catholics and Protestants. Rather, we expected that individuals are united in their opposition to secular policies and the type of society those (might) create, 
making the religious-secular divide the more important cleavage. This hypothesis was clearly confirmed: we found a statistically reliable difference between the Catholic-Protestant cleavage on the one hand and the secular-religious division on the other and we confirmed that the secular-religious cleavage is more important in shaping redistribution preferences.

On the contextual level we expected that, in addition to the effects of welfare state characteristics, religious polarization decreases the overall support for redistribution. Using a refined measure from the theoretical literature (Esteban and Ray 1994), our analysis reveals that a country's degree of religious polarization does indeed affect the preferences of its citizen's: increased antagonism between secular and religious groups leads to lower support for redistribution. Regarding welfare state characteristics, we went beyond the dominant 'regime dummy approach' to measuring welfare policies. We found that more liberal welfare polices also lead to opposition to redistribution, whereas traditional conservative policies increase the level of support.

The results of this paper suggest, that religion is an important factor, that should not be ignored in research on the causes and consequences of welfare states. We argue that that the literature's predominant focus on social class as a major cleavage in advanced industrial societies underestimates the importance of religion as part of the "social bases of politics" (Lipset 1983). In the process of secularization, large scale religious organizations may have lost their power to influence policy making directly. However, religion continues to influence individual's attitudes and beliefs - which are not restricted to questions of 'private morale'. Rather, the religious-secular cleavage shapes individual's political preferences in predicable ways, rivaling the effect of more established factors.

\section{References}

Abayomi, K., Gelman, A. and Levy, M. (2008). Diagnostics for multivariate imputations. Journal of the Royal Statistical Society C, 57, 273-291.

Agresti, A. (2002). Categorical Data Analysis. Hoboken: Wiley.

Alber, J. (1984). Versorgungsklasse im Wohlfahrtsstaat [Transfer class in the welfare state]. Kölner Zeitschrift für Soziologie und Sozialpsychologie, 36, 225-251.

Alesina, A., Devleeschauwer, A., Easterly, W., Kurlat, S. and Wacziarg, R. (2003). Fractionalization. Journal of Economic Growth, 8, 155-194.

Allison, P. D. (2001). Missing Data. Thousand Oaks: Sage.

Andreß, H.-J. and Heien, T. (2001). Four Worlds of Welfare Attitudes. A Comparison of Germany, Norway, and the United States. European Sociological Review, 17, 337-356.

Armingeon, K., Leimgruber, P., Beyeler, M. and Menegale, S. (2008). Comparative Political Data Set 1960-2006. Institute of Political Science, University of Berne. 
Arts, W. and Gelissen, J. (2001). Welfare States, Solidarity and Justice Principles: Does the Type Really Matter? Acta Sociologica, 44, 283-299.

Bean, C. and Papadakis, E. (1998). A Comparison Of Mass Attitudes Towards The Welfare State In Different Institutional Regimes, 1985-1990. International Journal of Public Opinion Research, 10, 211-236.

Blekesaune, M. (2007). Economic Conditions and Public Attitudes to Welfare Policies. European Sociological Review, 23, 393-403.

Blekesaune, M. and Quadagno, J. (2003). Public Attitudes toward Welfare State Policies: a Comparative Analysis of 24 Nations. European Sociological Review, 19, 415-427.

Brooks, C., Nieuwbeerta, P. and Manza, J. (2006). Cleavage-based voting behavior in crossnational perspective: Evidence from six postwar democracies. Social Science Research, 35, 88-128.

Brooks, S. P. and Roberts, G. O. (1998). Convergence assessment techniques for Markov chain Monte Carlo. Statistics and Computing, 8, 319-335.

Buuren, S. v. (2007). Multiple imputation of discrete and continuous data by full conditional specification. Statistical Methods in Medical Research, 16, 219-242.

Buuren, S. v., Brand, J. P. L., Groothuis-Oudshoorn, C. G. M. and Rubin, D. B. (2006). Fully conditional specification in multivariate imputation. Journal of Statistical Computation and Simulation, 76, 1049-1064.

Castles, F. G. (1994a). On religion and public policy: Does Catholicism make a difference? European Journal of Political Research, 25, 19-40.

Castles, F. G. (1994b). On religion and public policy: The case for covariance. European Journal of Political Research, 26, 111-115.

Chen, D. L. and Lind, J. T. (2006). The Political Economy of Beliefs: Why Fiscal and Social Conservatives and Liberals Come Hand-in-Hand. Paper presented at the annual meeting of the American Political Science Association, Philadelphia, 2006.

Clark, A. and Lelkes, O. (2005). Deliver us from evil: religion as insurance. European Centre for Social Welfare Policy Research. Papers on Economics of Religion 06/03.

Congdon, P. (2006). Bayesian Statistical Modeling. Chichester: Wiley.

Congdon, P. M. (2005). Bayesian Models for Categorical Data. Chichester: Wiley.

De Graaf, N. D., Heath, A. and Need, A. (2001). Declining cleavages and political choices: the interplay of social and political factors in the Netherlands. Electoral Studies, 20, 1-15.

Deacon, A. (2002). Perpsectives on Welfare. Buckingham: Open University Press. 
Duclos, J.-Y., Esteban, J. and Ray, D. (2004). Polarization: Concepts, Measurement, Estimation. Econometrica, 72, 1737-1772.

Edlund, J. (2006). Trust in the Capability of the Welfare State and General Welfare State Support: Sweden 1997-2002. Acta Sociologica, 49, 395-417.

Elff, M. (2007). Social Structure and Electoral Behavior in Comparative Perspective: The Decline of Social Cleavages in Western Europe Revisited. Perspectives on Politics, 5, 277294.

Erikson, R., Goldthorpe, J. H. and Portocarero, L. (1979). Intergenerational Class Mobility in Three Western European Societies: England, France and Sweden. British Journal of Sociology, 30, 415-441.

Esping-Andersen, G. (1990). The Three World of Welfare Capitalism. Cambridge: Polity Press.

Esping-Andersen, G. (1999). Social Foundations of Postindustrial Economies. Oxford: Oxford University Press.

Esteban, J.-M. and Ray, D. (1994). On the Measurement of Polarization. Econometrica, 62, 819-851.

Evans, G. (1996). Cross-national differences in support for welfare and redistribution: an evaluation of competing theories. In Taylor, B. and Thomson, K. (Eds.), Understanding Change in Social Attitudes, Dartmouth: Aldershot.

Gelissen, J. (2000). Popular support for institutionalised solidarity: a comparison between European welfare states. International Journal of Social Welfare, 9, 285-300.

Gelman, A., Carlin, J. B., Stern, H. S. and Rubin, D. B. (2004). Bayesian Data Analysis. Boca Raton: Chapman \& Hall.

Gelman, A. and Rubin, D. (1992). Inference from Iterative Simulation Using Multiple Sequences. Statistical Science, 7, 457-511.

Gelman, A. and Stern, H. (2006). The Difference between 'Significant' and 'Not Significant' is not Itself Statistically Significant. The American Statistician, 60, 328-331.

Gill, J. (2008). Bayesian Methods. A Social and Behavioral Sciences Approach. Boca Raton: Chapman \& Hall.

Goldthorpe, J. H. (1995). The service class revisited. In Butler, T. and Savage, M. (Eds.), Social change and the middle classes, London: UCL Press. pp. 313-329.

Goldthorpe, J. H. and McKnight, A. (2006). The Economic Basis of Social Class. In Morgan, S. L., Grusky, D. B. and Fields, G. S. (Eds.), Mobility and Inequality: Frontiers of Research in Sociology and Economics, Stanford: Stanford University Press. pp. 109-136. 
Groves, R. M., Dillman, D. A., Eltinge, J. L. and Little, R. J. A. (2001). Survey Nonresponse. Hoboken: Wiley.

Hasenfeld, Y. and Rafferty, J. A. (1989). The Determinants of Public Attitudes toward the Welfare State. Social Forces, 67, 1027-1048.

Hicks, A. (2006). Comment on Somers and Block, ASR, April 2005: Free-Market and Religious Fundamentalists versus Poor Relief. American Sociological Review, 71, 503-510.

Hicks, A. and Kenworthy, L. (2003). Varieties of welfare capitalism. Socio-economic review, 1, 27-61.

Huber, E. and Stephens, J. D. (2001). Development and Crisis of the Welfare State. Parties and Policies in Global Markets. Chicago: University of Chicago Press.

Inglehart, R. (1997). Modernization and Postmodernization. Cultural, Economic, and Political Change in 43 Societies. Princeton: Princeton University Press.

Iversen, T. and Soskice, D. (2001). An Asset Theory of Social Policy Preferences. American Political Science Review, 95, 875-893.

Kahl, S. (2005). The Religious Roots of Modern Poverty Policy: Catholic, Lutheran, and Reformed Protestant Traditions Compared. European Journal of Sociology, 46, 91-126.

Kersbergen, K. v. (1995). Social Capitalism: A Study of Christian Democracy and the Welfare State. London: Routledge.

King, G., Honacker, J., Anne, J. and Kenneth, S. (2001). Analyzing Incomplete Political Science Data: An Alternative Algorithm for Multiple Imputation. American Political Science Review, 95, 49-69.

Kuhnle, S. (Ed.) (2000). Survival of the European Welfare State. New York: Rout.

Lee, S.-Y. (2007). Structural Equation Modelsing. A Bayesian Approach. Chichester: Wiley.

Linos, K. and West, M. (2003). Self-interest, Social Beliefs and Attitudes toward Redistributioin. Re-addressing the Issue of Cross-national Variation. European Sociological Review, 19, 393-409.

Lipset, S. M. (1983). Political Man. The Social Bases of Politics. London: Heinemann.

Lipset, S. M. and Rokkan, S. (1967). Cleavage Structures, Party Systems, and Voter Alignments: An introduction. In Party Systems and Voter Alignments. Cross-National Perspectives, New York: Free Press. pp. 1-64.

Lipsmeyer, C. and Nordstrom, T. (2003). East versus West: comparing political attitudes and welfare preferences across European societies. Journal of European Public Policy, 10, 339364. 
Little, R. J. and Rubin, D. B. (2002). Statistical Analysis with Missing Data. Hoboken: Wiley.

Lynch, S. M. (2007). Introduction to Applied Bayesian Statistics and Estimation for Social Scientists. New York: Springer.

Madeley, J. (1991). Politics and religion in Western Europe. In Moyser, G. (Ed.), Politics and religion in the modern world, London: Routledge. pp. 28-66.

Manow, P. (2002). The good, the bad, and the ugly - Esping-Andersen's regime typology and the religious roots of the western welfare state. Kölner Zeitschrift für Soziologie und Sozialpsychologie, 54, 203-225.

Manow, P. and Kersbergen, K. v. (2008). Religion and the Western Welfare State - The Theoretical Context. In Kersbergen, K. v. and Manow, P. (Eds.), Religion, Class Coalitions and Welfare State Regimes, Cambridge University Press. pp. 4-33.

Manza, J. and Brooks, C. (1997). The Religious Factor in U.S. Presidential Elections, 19601992. American Journal of Sociology, 103, 38-81.

McCullagh, P. (1980). Regression Models for Ordinal Data. Journal of the Royal Statistical Society B, 42, 109-142.

Mehrtens III, J. F. (2004). Three worlds of public opinion? Values, variation and the effect on social policy. International Journal of Public Opinion Research, 16, 115-143.

Meier-Jaeger, M. (2006). What Makes People Support Public Responsibility for Welfare Provision: Self-interest or Political Ideology? Acta Sociologica, 49, 321-338.

Meier-Jaeger, M. (2008). Does left-right orientation have a causal effect on support for redistribution? Causal analysis with cross-sectional data using Instrumental Variables. International Journal of Public Opinion Research, 20, 363-373.

Meier-Jaeger, M. (2009). United But Divided: Welfare Regimes and the Level and Variance in Public Support for Redistribution. European Sociological Review, 25, 723-737.

Meltzer, A. and Richards, S. (1981). A rational theory of the size of government. Journal of Political Economy, 89, 914-927.

Moene, K. O. and Wallerstein, M. (2001). Inequality, Social Insurance and Redistribution. American Political Science Review, 95, 859-874.

Molenberghs, G. and Verbeke, G. (2005). Models for Discrete Longitudinal Data. New York: Springer.

Montalvo, J. G. and Reynal-Querol, M. (2002). Why ethnic fractionalization? Polarization, ethnic conflict and growth. Manuscript.

Montalvo, J. G. and Reynal-Querol, M. (2005a). Ethnic diversity and economic development. Journal of Development Economics, 76, 293-323. 
Montalvo, J. G. and Reynal-Querol, M. (2005b). Ethnic polarization, potential conflict and civil wars. American Economic Review, 95, 796-815.

OECD (2004a). Benefits and Wages. Paris: OECD.

OECD (2004b). Employment Outlook. Paris: OECD.

OECD (2005). Pensions at a glance. Paris: OECD.

OECD (2006). Economic Survey: Luxembourg. Paris: OECD.

OECD (2008a). Family Database. Paris: OECD.

OECD (2008b). Social Expenditure Database (SocX). Paris: OECD.

OECD (2009). Growing Unequal? Income Distribution and Poverty in OECD Countries. Paris: OECD.

Olson, L. R. and Green, J. C. (2006). The Religion Gap. Political Science and Politics, 39, 455-459.

van Oorschot, W. (2000). Who should get what, and why? On deservingness criteria and the conditionality of solidarity among the public. Policy \& Politics, 28, 33-48.

van Oorschot, W. (2006). Making the difference in social Europe: deservingness perceptions among citizens of European welfare states. Journal of European Social Policy, 16, 23-42.

van Oorschot, W. (2010). Public perceptions of the economic, moral, social, and migration consequences of the welfare state: an empirical analysis of welfare state legitimacy. Journal of European Social Policy, 20, 19-31.

van Oorschot, W., Arts, W. and Halman, L. (2005). Welfare state effects on social capital and informal solidarity in the European Union: evidence from the 1999/2000 EuropeanValues Study. Policy \& Politics, 33, 33-54.

Orloff, A. S. (1993). Gender and the Social Rights of Citizenship: The Comparative Analysis of Gender Relations and Welfare States. American Sociological Review, 58, 303-328.

Papadakis, E. and Bean, C. (1993). Popular Support for the Welfare State: A Comparison Between Institutional Regimes. Journal of Public Policy, 13, 228-254.

Pergament, K. (1997). The Psychology of Religion and Coping: Theory, Research, Practice. New York: Guilford Press.

Pergament, K. (2002). The Bitter and the Sweet: An Evaluation of the Costs and Benefits of Religiousness. Psychological Inquiry, 13, 168-181.

Permanyer, I. (2008). Social Polarization: Introducing distances between and within groups. Manuscript. 
Pierson, P. (2001). Coping with Permanent Austerity. Welfare State Restructuring in Affluent Democracies. In Pierson, P. (Ed.), The New Politics of the Welfare State., Oxford: Oxford University Press. pp. 410-456.

Raftery, A. E. (1995). Bayesian Model Selection in Social Research. Sociological Methodology, 35, 111-163.

Raghunathan, T. E., Lepkowski, J. M., Van Hoewyk, J. and Solenberger, P. (2001). A Multivariate Technique for Multiply Imputing Missing Values Using a Sequence of Regression Models. Survey Methodology, 27, 85-95.

Rose, D. and Harrison, E. (Eds.) (2010). Social Class in Europe: An Introduction to The European Socio-economic Classification. London: Routledge.

Rossteutscher, S. (2009). Religion, Zivilgesellschaft, Demokratie [Religion, Civil Society, Democracy]. Baden Baden: Nomos.

Rubin, D. (1987). Multiple Imputation for Nonresponse in Surveys. Hoboken: Wiley.

Rubin, D. (1996). Multiple Imputation After 18+ Years. Journal of the American Statistical Association, 91, 473-489.

Rudolph, T. J. and Jillian, E. (2005). Political Trust, Ideology, and Public Support for Government Spending. American Journal of Political Science, 49, 660-671.

Scheve, K. and Stasavage, D. (2006). Religion and Preferences for Social Insurance. Quarterly Journal of Political Science, 1, 255-286.

Schneider, A. and Ingram, H. (1993). Social Construction of Target Populations: Implications for Politics and Policy. American Political Science Review, 87, 334-347.

Scruggs, L. (2006). The generosity of social insurance, 1971-2002. Oxford Review of Economic Policy, 22, 349-364.

Scruggs, L. and Allan, J. (2006). Welfare-state decommodification in 18 OECD countries: a replication and revision. Journal of European Social Policy, 16, 55-72.

Scruggs, L. L. and Allan, J. P. (2008). Social Stratification and Welfare Regimes for the TwentyFirst Century. Revisiting the Three Worlds of Welfare Capitalism. World Politics, 60, 642664.

Shayo, M. (2009). A Model of Social Identity with an Application to Political Economy: Nation, Class, and Redistribution. American Political Science Review, 103, 147-174.

Siaroff, A. (1999). Corporatism in 24 industrial democracies: Meaning and measurement. European Journal of Political Research, 36, 175-205.

Stark, R. and Iannaccone, L. (1994). A Supply-Side Reinterpretation of the 'Secularization' of Europe. Journal for the Scientific Study of Religion, 33, 230-252. 
Stoop, I. (2005). The hunt for the last respondent: nonresponse in sample surveys. The Hague, The Netherlands: Social and Cultural Planning Office.

Sun, D., Speckman, P. L. and Tsutakawa, R. K. (2000). Random Effects in Generalized Linear Mixed Models (GLMMs). In Dey, D. K., Ghosh, S. K. and Mallick, B. (Eds.), Generalized Linear Models: A Bayesian Perspective, New York: Marcel Dekker. pp. 23-39.

Svallfors, S. (1993). Dimensions of Inequality. A Comparison of Attitudes in Britain and Sweden. European Sociological Review, 9, 267-287.

Svallfors, S. (1997). Worlds of Welfare and Attitudes to Redistribution: A Comparison of Eight Western Nations. European Sociological Review, 13, 283-304.

Svallfors, S. (1999). Political trust and attitudes towards redistribution A comparison of Sweden and Norway. European Societies, 1, 241-268.

Svallfors, S. (2002). Political Trust and Support for the Welfare State: Unpacking a Supposed Relationship. In Rothstein, B. and Steinmo, S. (Eds.), Restructuring the Welfare State: political institutions and policy change, New York: Palgrave Macmillan. pp. 184-205.

Svallfors, S. (2003). Welfare Regimes and Welfare Opinions. Social Indicators Research, 64, 495-520.

Svallfors, S. (2004). Class, Attitudes and the Welfare State: Sweden in Comparative Perspective. Social Policy \& Administration, 38, 119-138.

Svallfors, S. (2007). Introduction. In Svallfors, S. (Ed.), The Political Sociology of the Welfare State, Institutions, Social Change, and Orientations, Stanford: Stanford University Press. pp. $1-29$.

de Swaan, A. (1988). In Care Of The State. Health Care, Education And Welfare In Europe And The Usa In The Modern Era. Oxford: Oxford University Press.

Swank, D. (2002). Global capital, political institutions, and policy change in developed welfare states. Cambridge: Cambridge University Press.

Swank, D. (2005). Globalisation, Domestic Politics, and Welfare State Retrenchment in Capitalist Democracies. Social Policy \& Society, 4, 183-195.

Taylor-Gooby, P. (2001). Sustaining the welfare state in hard times: who will foot the bill? Journal of European Social Policy, 11, 133-147.

Wiepking, P. and Bekkers, R. (2009). Explaining Differences in Charitable Giving in Europe In Ganzenboom, H, and Wittenberg, M. (Eds.), Nederland in Vergelijkend Perspectief. Tweede Nederlandse workshop European Social Survey, Den Haag: DANS. pp. 185-191.

Wuthnow, R. (1988). The Restructuring of American Religion: Society and Faith since World War II. Princeton: Princeton University Press. 